\title{
THE USE OF MOSSES IN BIOMONITORING OF SELECTED AREAS IN POLAND AND SPITSBERGEN IN THE YEARS FROM 1975 TO 2014
}

\author{
WYKORZYSTANIE MCHÓW W BIOMONITORINGU \\ WYBRANYCH OBSZARÓW W POLSCE I NA SPITSBERGENIE \\ W LATACH 1975-2014
}

\begin{abstract}
We have compared historical changes in concentrations of the heavy metals $\mathrm{Mn}, \mathrm{Ni}, \mathrm{Cu}, \mathrm{Zn}, \mathrm{Cd}$ and $\mathrm{Pb}$ accumulated in samples from the Polish woodlands of Beskidy and Karkonosze (S, SE Poland) and the north-east regions of the country, versus the relatively little polluted areas of Spitsbergen of the Svalbard Archipelago. We have combined the results from literature with new results from 2014. The regions of Beskidy and Karkonosze were the most exposed to heavy metals deposition. However, from 1975 to 2014 there was a considerable decrease of concentrations of $\mathrm{Cu}, \mathrm{Zn}, \mathrm{Cd}$ and $\mathrm{Pb}$ at all Polish sites, clearly signifying improvement of environmental quality. For example, the average Cd concentration in mosses samples collected in Karkonosze decreased from $0.002 \mathrm{mg} / \mathrm{g}$ in 1975 to $0.0006 \mathrm{mg} / \mathrm{g}$ in 2014 . It is interesting to observe relatively large concentrations of nickel in moss samples collected in 2014 in the Svalbard archipelago, in the vicinity of Longyearbyen (average $0.018 \mathrm{mg} / \mathrm{g}$ ) which most likely originate from local mine waste piles.
\end{abstract}

Keywords: air pollutions, biomonitoring, heavy metals, mosses, Poland, Svalbard

\footnotetext{
${ }^{1}$ Chair of Biotechnology and Molecular Biology, Opole University, ul. kard. B. Kominka 6, 45-032 Opole, Poland, phone +48 7740160 42, email: aklos@uni.opole.pl, ziembik@uni.opole.pl, mrajfur@o2.pl, agna@uni.opole.pl,kremspawel@gmail.com,dominik.jerz@gmail.com, marysia.zielinska@gmail.com ${ }^{2}$ Institute of Geodesy and Cartography, ul. Z. Modzelewskiego 27, 02-679 Warszawa, email: zbigniew.bochenek@igik.edu.pl,dariusz.ziolkowski@igik.edu.pl

${ }^{3}$ Norwegian Institute for Nature Research - NINA, FRAM - High North Research Centre for Climate and the Environment, PO Box 6606 Langnes, NO-9296 Tromsø, email: jarle.werner.bjerke@nina.no, Hans.Tommervik@nina.no

${ }^{4}$ Department of Geoinformatics, Cartography and Remote Sensing, Faculty of Geography and Regional Studies, University of Warsaw, ul. Krakowskie Przedmieście 30, 00-927 Warszawa, email: bogdan@uw.edu.pl

*Corresponding author: aklos@uni.opole.pl
} 


\section{Introduction}

Emission of heavy metals to the atmosphere may, due to dry and wet deposition, cause local enrichment of surface layers of the lithosphere and contamination of the hydrosphere in emission of heavy metals to the atmosphere may, due to dry and wet deposition, cause local enrichment of surface layers of the lithospere and contamination of the hydrosphere in amounts which are detrimental to ecosystems. Heavy metals introduced to ecosystems participate in mass exchange between biocenosis and biotope, and by building into subsequent elements of trophic chains, they frequently end up in human organisms. Global effects are also a problem, which is exemplified by, among others, mercury. Due to the specific physicochemical properties of this element, eg melting temperature $(234.32 \mathrm{~K})$, high volatility and ability for biotransformation (metisation, dealkylation and reduction), mercury can transfer between air, soil and water [1]. In the air, that mercury vapors travel on long distances, what is confirmed by the increasing concentrations of the element in Arctic regions [2].

Currently, the instrumental methods for analysis of environmental pollution are effectively supplemented or even substituted by methods using biological indices [3-6] and become "one of the pillars of modern environmental monitoring" [7]. Their obvious advantages are a cheap and simple method of visual assessment of species diversity and external symptoms of changes caused by human pressure. This method of using the organisms, which are referred to as bioindicators, allows to perform a qualitative assessment of changes in the environment. Another approach includes the quantitative assessment of changes in the environment. For this purpose, concentrations of the macro- and microelements accumulated in organisms (biomonitors) are most frequently determined. This allows to assess the level of deposition of pollutants in the studied areas and determine sources and directions of their distribution, as well as assess changes taking place in ecosystems in a historical perspective. Biomonitoring research is frequently supplemented by soil analyses, from which pollutants are transferred to the green parts of plants through the root systems [8]. The soil is also a secondary source of atmospheric aerosol pollution [9]. The radioactive isotope ${ }^{137} \mathrm{Cs}$, released during the Chernobyl reactor breakdown in 1986 and still present in the forest soils in Poland, among others, is a good marker of these processes [10].

Trace elements in mosses were determined already during the 1960s [11]. Approved analytical methods are currently used to determine the elemental composition. The concentrations of the elements detected by the absorption (AAS) and emission (AES) atomic spectrometry are of the ppm order (parts per million), ie millionth parts of a sample mass $\left(10^{-4} \%\right)$. Mass spectrometry (MS) and instrumental neutron activation analysis (INAA) enable to identify the elements with concentrations of the ppb order (parts per billion), ie parts per billion $\left(10^{-7} \%\right)$. Application of the non-invasive methods X-ray fluorescence spectrometry (XRF) and proton-induced X-ray emission (PIXE) allows elements quantification on the ppm order. The quoted determination limit values are approximations. They depend on the type of the determined element and the applied research methodology.

Cyclic studies of heavy metals concentrations accumulated in mosses have been carried out in European countries every 5 years since 1990. The studies have been carried out within the International Cooperative Programme on Effects of Air Pollution on Natural 
Vegetation and Crops. The program is coordinated by ICP Vegetation Coordination Centre, Centre for Ecology and Hydrology, Bangor, UK. Areas are classified by heavy metal pollution level, and the potential changes are assessed and predicted. International, large-scale, integrated biomonitoring research is supplemented by smaller-scale studies, which cover states, regions or small-area ecosystems. Examples are, among others, the methodical studies carried out in Portugal since the 1990s, of trace elements accumulating in lichens $[12,13]$, studies of heavy metals accumulating in mosses and lichens collected in the Polish-Czech area [14, 15], or typical local research, for example the research carried out in order to determine the pollution sources [16].

The objective of the research presented herein is the assessment of changes at heavy metals concentrations in long term perspective, accumulating in mosses growing in Poland and the Svalbard archipelago, as well as the current assessment of heavy metals pollution level in these study areas.

\section{Characteristics of the areas covered by the project}

The research areas were selected considering the synthesis of information regarding the location and climate. The locations of the research areas in Poland are presented in the map in Figure 1.

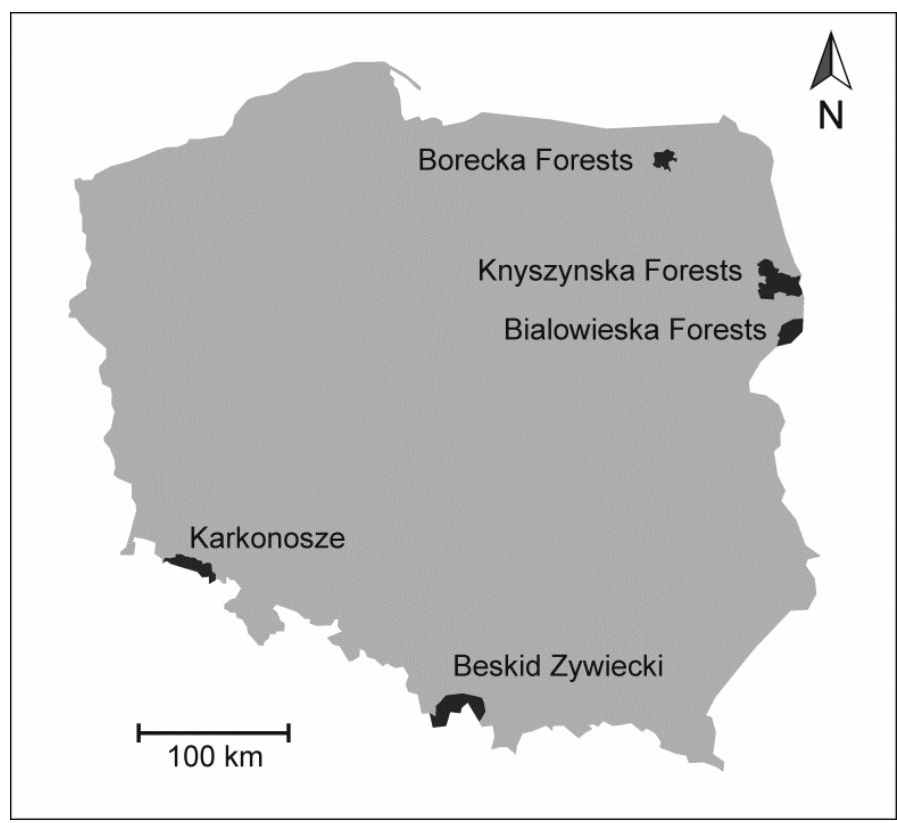

Fig. 1. The locations of the research areas in Poland

Karkonosze (Giant Mountains) are the highest range of the Sudety (Sudeten) mountains, located in south-western Poland (more than 28\%) and the Czech Republic. The highest peak in Karkonosze is Sniezka (1602 m above the sea level). The following two national parks were created in Karkonosze: Karkonosze National Park (in 1959) and 
Rudawy Landscape Park (in 1989). Atmospheric conditions in Karkonosze are mainly shaped by the oceanic air masses, which influence the length and severity of winters, considerable precipitation, large temperatures amplitude and strong winds. Thermal inversion occurs in valleys. The vegetation period, which is equal to the number of days with an average daily temperature above $5^{\circ} \mathrm{C}$, is usually shorter than 210 days a year. The area of Karkonosze was in the 1970s exposed to a strong emission of pollution from power plants fuelled by brown coal, located in the so called "Black triangle", including the crossborder areas of Czechoslovakia, East Germany and Poland.

Beskid Zywiecki is one of the three (Beskid Maly and Beskid Slaski) mountainous mesoregions located in the central part of southern Poland, within the macroregion of West Beskidy. The largest peaks of Beskid Zywiecki are Babia Gora (1725 m above the sea level), Gowniak (1617 $\mathrm{m}$ above the sea level) and Pilsko (1557 $\mathrm{m}$ above the sea level). The following national parks were established in Beskid Zywiecki: Babiogorski National Park (in 1954) and Zywiecki Landscape Park (in 1986), within which there are 10 nature reservations. Beskid Zywiecki is characterised by the differentiation of climate, both regarding temperatures and precipitation. The largest annual precipitation (more than $1300 \mathrm{~mm}$ ) is observed in upper mountain areas. Considerable drops of temperatures (thermal inversion) are noted in valleys, in particular during the winter-spring season. The weather is largely influenced by the masses of humid air of polar and sea origin $(65 \%$ during a year). The vegetation period in Beskid Zywiecki is from over 200 to approximately 160 (140) days in the upper mountain areas. The area of Beskidy, where gradual degradation of woodland ecosystems can be observed, is under the influence of the emission from the Upper Silesia Industrial Zone (PL) and Ostrava-Karvina Coal Basin (CZ).

The following forests are located in the north-eastern part of Poland: Bialowieska, Knyszynska and Augustowska (near the Belarus border), Borecka and Romincka (near the border with Kaliningrad Region) and the forests located near the Pisa and Narew rivers: Piska, Kurpiowska and Biala. The following national parks were established in this area: Bialowieski (in 1932), Wigierski (in 1989), Biebrzanski (in 1993) and Narwianski (in 1996). The Mazury National Park is currently established. The climate in this area is moderate continental, cool with the influence of the Atlantic climate. The annual precipitation is approximately $600 \mathrm{~mm}$. The length of vegetation period is not more than 210 days in a year in the Bialowieska forests. The flora differs from to that in central Poland, because of the presence of arctic and boreal species, as well as the expansion of spruce [17]. The areas of north-eastern Poland are little polluted, under the influence of distant and low emission from local sources.

Svalbard is a Norwegian province in the Arctic, covering several islands with the largest one, Spitsbergen. Norway administratres the area on the basis of the Spitsbergen Treaty. The archipelago borders with the Greenland Sea from the west, the Barents Sea from the east and the Arctic Ocean from the north. The archipelago area is $62924 \mathrm{~km}^{2}$. Approximately $60 \%$ of the Spitsbergen area is covered by glaciers and the rest is mountains and seaside lowlands. The perennial snow border is approximately from $200 \mathrm{~m}$ above the sea level in south-east to approximately $800 \mathrm{~m}$ above the sea level in the north, in the West Spitsbergen. The highest peaks are Newtontoppen with (1713 m a.s.l) and Perriertoppen, located in the northern part of the island. A number of nature reserves and national parks were established in the Svalbard archipelago, which cover $62.5 \%$ of the land and $84.7 \%$ of the sea area around the islands. The climate in Svalbard is typically middle to high Arctic. 
The Svalbard climate is largely shaped by the sea currents: the warm West Spitsbergen current and the cold currents: East Spitsbergen and Barents. The average year temperature in Svalbard is from -5.9 to $-0.9^{\circ} \mathrm{C}$. Precipitation is low, amounting to $200-300 \mathrm{~mm}$ per year. The snow cover lasts from the middle of September until the beginning of June. The climate in the area does not support growth of flora throughout the most part of the year. Permafrost melts only to the depth of $30-150 \mathrm{~cm}$ during the summer. Vegetation exists only in 6-7\% of the Svalbard area. Plants grow mainly in the narrow strip along the seaside, on mountain slopes and in some valleys. Growing season is very short and lasts maximum 90 days [18-22]. Long transported air pollution in Svalbard originates mainly from Central and Eastern Europe, among others from the industrial area in the Kola Peninsula and Siberia [23]. But the coal electrical power plants in Longyearbyen, Barentsburg and Ny-Ålesund may be also a source for local air pollution like $\mathrm{SO}_{2}$ and heavy metals [24]. Another source of pollution is winter-generated coal-mining pollution (eg heavy metals) released by thawing $[25,26]$ and flushed down from the piles (acid mine drainage - AMD). This kind of pollutants can be wind spread over larger areas around the mines and the rock piles. Other sources of pollution might originate from sea bird colonies (bird cliffs) in the area [27]. The latter indicates that the seabirds (faeces) are acting as a vector for the movement of heavy metals between the marine and terrestrial ecosystems. which can contribute significantly to spread of pollutants in the vicinities of such cliffs/colonies [27].

The location of Longyearbyen, the administrative center of Svalbard, around which the moss samples were collected, is presented in the map in Figure 2.

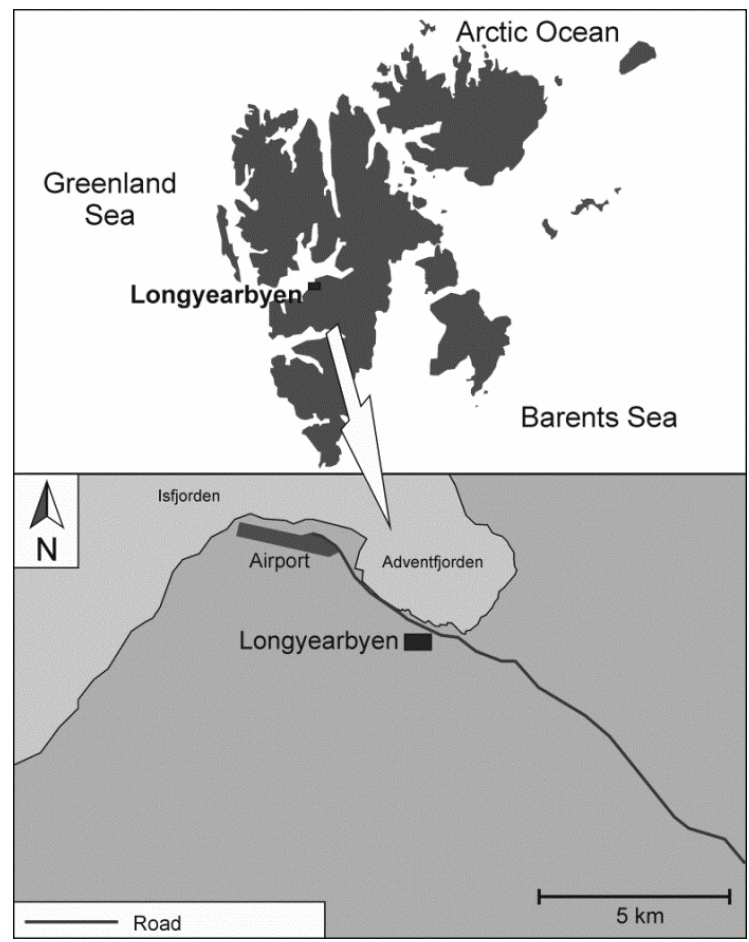

Fig. 2. The area around Longyearbyen in which the samples were collected 


\section{Materials and methods}

Samples of the epigeic moss Pleuroziom schreberi were collected for the research in Poland. Samples of epigeic moss Hylocomium splendens were collected in Svalbard. The collected samples were cleaned from impurities, dried at $323 \mathrm{~K}$ and stored in tightly sealed polyethylene containers. Homogenized samples with the mass of $0.4 \mathrm{~g}$ were mineralized in a mixture of nitric acid and hydrogen peroxide in a microwave mineralizer (Speedwave Four Berghof, DE). MERCK reagents were used to prepare the solutions. Concentrations of the following elements were determined in demineralized samples: $\mathrm{Mn}, \mathrm{Ni}, \mathrm{Cu}, \mathrm{Zn}, \mathrm{Cd}$ and $\mathrm{Pb}$, with the FAAS method, using the iCE 3000 spectrometer made by Thermo Electron Corporation (USA).

In Table 1, the instrumental detection limits $(I D L)$ and instrumental quantification limits $(I Q L)$ for the spectrometer iCE 3500 are presented. Calibration of the spectrometer was performed with a standard solution from ANALYTIKA Ltd. (Czech Republic). The values of the highest concentrations of the models used for calibration $\left(2 \mathrm{mg} / \mathrm{dm}^{3}\right.$ for $\mathrm{Cd}$, $5 \mathrm{mg} / \mathrm{dm}^{3}$ for $\mathrm{Ni}, \mathrm{Cu}, \mathrm{Zn}, \mathrm{Pb}$ and $7.5 \mathrm{mg} / \mathrm{dm}^{3}$ for $\mathrm{Mn}$ ) ware approved as linear limits of the signal dependence on the concentration.

Table 1

The instrumental detection limits $(I D L)$ and instrumental quantification limits $(I Q L)\left[\mathrm{mg} / \mathrm{dm}^{3}\right]$ for the spectrometer iCE 3500

\begin{tabular}{|c|c|c|}
\hline Metal & IDL & IQL \\
\hline $\mathrm{Mn}$ & 0.0016 & 0.020 \\
\hline $\mathrm{Ni}$ & 0.0043 & 0.050 \\
\hline $\mathrm{Cu}$ & 0.0045 & 0.033 \\
\hline $\mathrm{Zn}$ & 0.0033 & 0.010 \\
\hline $\mathrm{Cd}$ & 0.0028 & 0.013 \\
\hline $\mathrm{Pb}$ & 0.0130 & 0.070 \\
\hline
\end{tabular}

Table 2

Comparison of measured and certified concentrations in BCR-414 plankton and in BCR-482 lichen

\begin{tabular}{|c|c|c|c|c|c|}
\hline \multirow{3}{*}{ Metal } & \multicolumn{2}{|c|}{ BCR-414 plankton } & \multicolumn{2}{|c|}{$\mathbf{A A S}$} & \multirow{2}{*}{ Dev. ** } \\
\hline & Concentration & Uncertainty & Mean & $\pm S D *$ & \\
\hline & \multicolumn{4}{|c|}{ [mg/kg d.m.] } & {$[\%]$} \\
\hline $\mathrm{Mn}$ & 299 & 12 & 284 & 13 & -5.0 \\
\hline $\mathrm{Ni}$ & n.d & n.d & n.d & n.d & n.d \\
\hline $\mathrm{Cu}$ & 29.5 & 1.3 & 28.4 & 1.6 & -3.7 \\
\hline $\mathrm{Zn}$ & 112 & 3 & 107 & 3 & -4.5 \\
\hline $\mathrm{Cd}$ & 0.383 & 0.014 & n.d & n.d & n.d \\
\hline $\mathrm{Pb}$ & 3.97 & 0.19 & 3.75 & 0.21 & -5.5 \\
\hline \multirow{3}{*}{ Metal } & \multicolumn{2}{|c|}{ BCR-482 lichen } & \multicolumn{2}{|c|}{ AAS } & \multirow{2}{*}{ Dev. ** } \\
\hline & Concentration & Uncertainty & Mean & $\pm S D *$ & \\
\hline & \multicolumn{4}{|c|}{ [mg/kg d.m.] } & {$[\%]$} \\
\hline $\mathrm{Mn}$ & 33.0 & 0.5 & 31.7 & 0.68 & -3.9 \\
\hline $\mathrm{Ni}$ & 2.47 & 0.07 & 2.16 & 0.32 & -13 \\
\hline $\mathrm{Cu}$ & 7.03 & 0.19 & 6.63 & 0.17 & -5.7 \\
\hline $\mathrm{Zn}$ & 100.6 & 2.2 & 95.1 & 2.3 & -5.5 \\
\hline $\mathrm{Cd}$ & 0.56 & 0.02 & 0.53 & 0.03 & -5.3 \\
\hline $\mathrm{Pb}$ & 40.9 & 1.4 & 38.2 & 1.0 & -6.6 \\
\hline
\end{tabular}

* - standard deviation, ** - relative difference between determined and certified concentrations $100 \% \cdot\left(c_{z}-c_{c}\right) / c_{c}$, n.d. - not determined 
In Table 2, concentrations of heavy metals in certified reference materials BCR-414 plankton and BCR-482 lichen, produced by the Institute for Reference Materials and Measurements, Belgium, are shown.

\section{Results and discussion}

In Tables 3 and 4, concentrations of heavy metals accumulated in the mosses are presented (Karkonosze - K, Beskidy - B, Borecka Forest - PBo, Knyszynska Forest - PK and Bialowieska Forest - PBi) during the period from April till May, from June till July and from August till October 2014 and in Spitsbergen during the period 03-07.08.2014.

Table 3

Concentrations of $\mathrm{Mn}, \mathrm{Ni}, \mathrm{Cu}, \mathrm{Zn}, \mathrm{Cd}$ and $\mathrm{Pb}[\mathrm{mg} / \mathrm{g}]$ : mean (minimum-maximum) in Pleuroziom schreberi from the Polish study sites

\begin{tabular}{|c|c|c|c|c|c|}
\hline Metal & $\mathrm{K}$ & $\mathrm{B}$ & PBo & PK & $\mathrm{PBi}$ \\
\hline $\mathrm{Mn}$ & $\begin{array}{c}0.46 \\
(0.17-1.22) \\
\end{array}$ & $\begin{array}{c}0.59 \\
(0.06-2.07) \\
\end{array}$ & $\begin{array}{c}0.38 \\
(0.10-0.68) \\
\end{array}$ & $\begin{array}{c}0.48 \\
(0.17-0.81) \\
\end{array}$ & $\begin{array}{c}0.44 \\
(0.03-0.84) \\
\end{array}$ \\
\hline $\mathrm{Ni}$ & $\begin{array}{c}<0.0061 \\
(<0.0031-0.0130) \\
\end{array}$ & $\begin{array}{c}<0.0089 \\
(<0.0031-0.0169)\end{array}$ & $\begin{array}{c}<0.0057 \\
(<0.0031-0.0130)\end{array}$ & $\begin{array}{c}0.0047 \\
(0.0027-0.0099) \\
\end{array}$ & $\begin{array}{c}<0.0050 \\
(<0.0031-0.0069)\end{array}$ \\
\hline $\mathrm{Cu}$ & $\begin{array}{c}0.0102 \\
(0.0021-0.0348) \\
\end{array}$ & $\begin{array}{c}0.0084 \\
(0.0055-0.0132)\end{array}$ & $\begin{array}{c}0.0068 \\
(0.0039-0.0081) \\
\end{array}$ & $\begin{array}{c}0.0055 \\
(0.0032-0.0075) \\
\end{array}$ & $\begin{array}{c}0.0052 \\
(0.0023-0.0088)\end{array}$ \\
\hline $\mathrm{Zn}$ & $\begin{array}{c}0.035 \\
(0.013-0.089) \\
\end{array}$ & $\begin{array}{c}0.062 \\
(0.033-0.143) \\
\end{array}$ & $\begin{array}{c}0.039 \\
(0.022-0.055) \\
\end{array}$ & $\begin{array}{c}0.028 \\
(0.014-0.049) \\
\end{array}$ & $\begin{array}{c}0.038 \\
(0.024-0.100) \\
\end{array}$ \\
\hline $\mathrm{Cd}$ & $<0.0006$ & $\begin{array}{c}<0.0009 \\
(<0.0003-0.0013)\end{array}$ & $<0.0006$ & $<0.0006$ & $<0.0008$ \\
\hline $\mathrm{Pb}$ & $\begin{array}{c}<0.0052 \\
(<0.0018-0.0218)\end{array}$ & $\begin{array}{c}<0.0065 \\
(<0.0018-0.0317)\end{array}$ & $\begin{array}{c}<0.0041 \\
(<0.0018-0.0089)\end{array}$ & $\begin{array}{c}<0.0050 \\
(<0.0018-0.0145)\end{array}$ & $\begin{array}{c}<0.0048 \\
(<0.0018-0.0128)\end{array}$ \\
\hline
\end{tabular}

Concentrations of $\mathrm{Mn}, \mathrm{Ni}, \mathrm{Cu}, \mathrm{Zn}, \mathrm{Cd}$ and $\mathrm{Pb}[\mathrm{mg} / \mathrm{g}]$ : mean (minimum-maximum) in Hylocomium splendens from Spitsbergen

\begin{tabular}{|c|c|c|c|c|c|}
\hline $\mathrm{Mn}$ & $\mathrm{Ni}$ & $\mathrm{Cu}$ & $\mathrm{Zn}$ & $\mathrm{Cd}$ & $\mathrm{Pb}$ \\
\hline 0.104 & 0.018 & 0.0064 & 0.032 & $<0.0008$ & $<0.0044$ \\
$(0.044-0.174)$ & $(0.012-0.024)$ & $(0.0037-0.0144)$ & $(0.018-0.054)$ & & $<$ \\
\hline
\end{tabular}

The results presented in Tables 3 and 4 were supplemented with the data from literature. Table 5 presents mean values of concentrations of the heavy metals accumulated in mosses Hylocomium splendens and Pleurozium schreberi collected for the analysis in the area of the following national parks: Babiogorski, Karkonoski and Bialowieski during the years: 1975 [28] 1976 and 1986 [29] and in 1990 and 1995 [30-32].

Another example of a long-term research regarding determination of heavy metals accumulated in mosses is the research carried out in Bialowieska Forest during the period 1994-2009. Results of the research published in [33, 34] are shown in Table 6.

Biomonitoring was carried out also in 1998 in Bialowieska, Knyszynska, Augustowska, Borecka and Romnicka Forests [35]. Pleurozium schreberi was used in the research. The results of mean concentration values of the selected metals are presented in Table 7.

Another example is the research carried out in Karkonosze, which regarded pollution of peat bog ecosystems with heavy metals, with the use of peatmoss (Sphagnum). The following peatmoss species were collected: Sphagnum cuspidatum, S. lindbergii, S. majus, 
S. tenellum, S. magellanicum, S. papillosum and S. russowii [36]. Mean concentrations are shown in Table 8.

Table 5

Concentrations of heavy metals in samples of mosses Pleurozium schreberi $(P S)$ and Hylocomium splendens $(H S)$ collected for the research in the following national parks: Bialowieski, Babiogorski and Karkonoski during the years 1975-1995

\begin{tabular}{|c|c|c|c|c|c|c|c|c|}
\hline \multirow{2}{*}{ Element } & \multirow{2}{*}{$\begin{array}{c}\text { Name } \\
\text { of Park }\end{array}$} & \multirow{2}{*}{ Moss } & \multicolumn{6}{|c|}{ Years } \\
\hline & & & $1975^{1}$ & $1975^{2}$ & $1976^{3}$ & $1986^{3}$ & $1990^{4}$ & $1995^{2}$ \\
\hline \multicolumn{9}{|c|}{$[\mathrm{mg} / \mathrm{g}]$} \\
\hline \multirow{6}{*}{$\mathrm{Mn}$} & \multirow{2}{*}{ Babiogorski } & $P S$ & 0.24 & - & 0.22 & 0.10 & - & - \\
\hline & & $H S$ & 0.12 & - & - & & - & - \\
\hline & \multirow{2}{*}{ Karkonoski } & $P S$ & 0.32 & - & 0.20 & 0.18 & - & - \\
\hline & & $H S$ & - & - & - & - & - & - \\
\hline & \multirow{2}{*}{ Bialowieski } & $P S$ & 0.48 & - & 0.490 & 0.20 & - & - \\
\hline & & $H S$ & 0.40 & - & - & - & - & - \\
\hline \multirow{6}{*}{$\mathrm{Ni}$} & \multirow{2}{*}{ Babiogorski } & $P S$ & 0.0076 & 0.0044 & 0.0077 & 0.0048 & $0.0038-0.0045$ & $0.0020-0.0030$ \\
\hline & & $H S$ & 0.0076 & - & - & - & - & - \\
\hline & \multirow{2}{*}{ Karkonoski } & $P S$ & - & 0.0076 & 0.0075 & 0.0039 & $0.0023-0.0030$ & $0.0020-0.0030$ \\
\hline & & $H S$ & 0.0072 & - & - & - & - & - \\
\hline & \multirow{2}{*}{ Bialowieski } & $P S$ & 0.0036 & 0.0023 & 0.0038 & 0.0028 & $0.0015-0.0023$ & $0.0010-0.0020$ \\
\hline & & $H S$ & 0.0036 & - & - & - & - & - \\
\hline \multirow{6}{*}{$\mathrm{Cu}$} & \multirow{2}{*}{ Babiogorski } & $P S$ & 0.0148 & - & - & - & $0.012-0.014$ & $0.008-0.012$ \\
\hline & & $H S$ & 0.0100 & - & - & - & - & - \\
\hline & \multirow{2}{*}{ Karkonoski } & $P S$ & - & - & - & - & $0.014-0.018$ & $0.020-0.024$ \\
\hline & & $H S$ & 0.152 & - & - & - & - & - \\
\hline & \multirow{2}{*}{ Bialowieski } & $P S$ & 0.0128 & - & - & - & $0.008-0.010$ & $<0.008$ \\
\hline & & $H S$ & 0.0080 & - & - & - & - & - \\
\hline \multirow{6}{*}{$\mathrm{Zn}$} & \multirow{2}{*}{ Babiogorski } & $P S$ & 0.144 & - & 0.140 & 0.097 & $>0.110$ & $0.060-0.080$ \\
\hline & & $H S$ & 0.152 & - & - & - & - & - \\
\hline & \multirow{2}{*}{ Karkonoski } & $P S$ & 0.268 & - & 0.265 & 0.070 & $0.050-0.060$ & $0.040-0.060$ \\
\hline & & $H S$ & - & - & - & - & - & - \\
\hline & \multirow{2}{*}{ Bialowieski } & $P S$ & 0.076 & - & 0.079 & 0.050 & $0.040-0.050$ & $0.040-0.060$ \\
\hline & & $H S$ & 0.076 & - & - & - & - & - \\
\hline \multirow{6}{*}{$\mathrm{Cd}$} & \multirow{2}{*}{ Babiogorski } & $P S$ & 0.0028 & - & 0.0019 & 0.0013 & - & $0.00075-0.001$ \\
\hline & & $H S$ & 0.0020 & - & - & - & - & - \\
\hline & \multirow{2}{*}{ Karkonoski } & $P S$ & - & - & 0.0018 & 0.0007 & - & $0.00025-0.0005$ \\
\hline & & $H S$ & 0.0020 & - & - & - & - & - \\
\hline & \multirow{2}{*}{ Bialowieski } & $P S$ & - & - & 0.0018 & 0.0007 & - & $0.00025-0.0005$ \\
\hline & & $H S$ & 0.0020 & - & - & - & - & - \\
\hline & Pohiogorski & $P S$ & 0.184 & 0.109 & 0.180 & 0.100 & $>0.045$ & $0.020-0.040$ \\
\hline & Davivgor SNI & $H S$ & 0.136 & - & - & - & - & - \\
\hline $\mathrm{Ph}$ & Karkonoski & $P S$ & 0.084 & 0.021 & 0.089 & 0.082 & $>0.045$ & $0.010-0.040$ \\
\hline ro & NAIKUIUSKI & $H S$ & - & - & - & - & - & - \\
\hline & Rinlowieck & $P S$ & 0.060 & 0.034 & 0.063 & 0.039 & $0.015-0.020$ & $0.010-0.020$ \\
\hline & Blalowiesk1 & $H S$ & 0.056 & - & - & - & - & - \\
\hline
\end{tabular}

${ }^{1}[28],{ }^{2}[31],{ }^{3}[29],{ }^{4}[30]$ 
Table 6

Mean content of heavy metals $[\mathrm{mg} / \mathrm{g}]$ in mosses Pleurozium schreberi collected for the research in Bialowieska Forest during the period 1994-2009 [33, 34]

\begin{tabular}{|c|c|c|c|c|c|c|}
\hline Years & Mn & Ni & Cu & Zn & Cd & Pb \\
\hline 1994 & 0.317 & 0.0147 & 0.0059 & 0.0545 & 0.00050 & 0.0105 \\
\hline 1995 & 0.284 & 0.0076 & 0.0050 & 0.0484 & 0.00043 & 0.0101 \\
\hline 1996 & 0.360 & 0.0048 & 0.0042 & 0.0431 & 0.00039 & 0.0112 \\
\hline 1997 & 0.317 & 0.0077 & 0.0036 & 0.0494 & 0.00045 & 0.0120 \\
\hline 1998 & 0.376 & 0.0058 & 0.0047 & 0.0484 & 0.00043 & 0.0098 \\
\hline 1999 & 0.371 & 0.0076 & 0.0054 & 0.0459 & 0.00040 & 0.0079 \\
\hline 2000 & 0.357 & 0.0060 & 0.0043 & 0.0415 & 0.00034 & 0.0060 \\
\hline 2001 & 0.302 & 0.0056 & 0.0046 & 0.0382 & 0.00031 & 0.0061 \\
\hline 2002 & 0.389 & 0.0088 & 0.0050 & 0.0443 & 0.00030 & 0.0062 \\
\hline 2003 & 0.391 & 0.0079 & 0.0064 & 0.0412 & 0.00037 & 0.0061 \\
\hline 2004 & 0.331 & 0.0059 & 0.0057 & 0.0517 & 0.00030 & 0.0052 \\
\hline 2005 & 0.297 & 0.0061 & 0.0058 & 0.0426 & 0.00030 & 0.0065 \\
\hline 2006 & 0.381 & 0.0048 & 0.0079 & 0.0597 & 0.00032 & 0.0054 \\
\hline 2007 & 0.342 & 0.0041 & 0.0058 & 0.0368 & 0.00030 & 0.0054 \\
\hline 2008 & 0.282 & 0.0049 & 0.0069 & 0.0402 & 0.00025 & 0.0052 \\
\hline 2009 & 0.322 & 0.0047 & 0.0080 & 0.0363 & 0.00034 & 0.0048 \\
\hline
\end{tabular}

Table 7

Mean values of heavy metals concentrations [mg/g] in mosses Pleurozium schreberi collected in 1998 in Bialowieska, Knyszynska, Augustowska, Borecka and Romincka Forests [35]

\begin{tabular}{|c|c|c|c|c|c|c|}
\hline Year & Mn & Ni & Cu & Zn & Cd & Pb \\
\hline 1998 & - & - & 0.0052 & 0.070 & 0.0005 & 0.0105 \\
\hline
\end{tabular}

Table 8

Mean content of heavy metals $[\mathrm{mg} / \mathrm{g}]$ in peatmoss collected for the research in 1986 and 2011 from peat bogs located in Karkonosze [36]

\begin{tabular}{|c|c|c|c|c|c|c|}
\hline Years & Mn & Ni & Cu & Zn & Cd & Pb \\
\hline 1986 & 0.35 & 0.0018 & 0.008 & 0.077 & 0.0008 & 0.069 \\
\hline 2011 & 0.77 & 0.0007 & 0.004 & 0.045 & 0.0003 & 0.009 \\
\hline
\end{tabular}

Svalbard is considered as an ecologically clean benchmark area, indicating the global pollution level. Previous biomonitoring results from Svalbard are here presented briefly.

Table 9 presents results of the research carried out in 1985 in the south-western part of Svalbard. $\mathrm{Ni}, \mathrm{Cu}, \mathrm{Zn} \mathrm{Cd}$ and $\mathrm{Pb}$ were determined in 16 moss species [37].

Table 9

Mean concentrations of heavy metals $\mathrm{Ni}, \mathrm{Cu}, \mathrm{Zn} \mathrm{Cd}$ and $\mathrm{Pb}$ accumulated in mosses collected in Svalbard

in 1985 [mg/g]. The table presents mean values and standard deviation from the mean value $( \pm S D)$ [37]

\begin{tabular}{|c|c|c|c|c|c|c|}
\hline Mosses & $\mathbf{M n}$ & $\mathbf{N i}$ & $\mathbf{C u}$ & $\mathbf{Z n}$ & $\mathbf{C d}$ & $\mathbf{P b}$ \\
\hline Aulacomnium palustre & - & 0.0083 & 0.0140 & 0.030 & 0.00083 & 0.0067 \\
\hline Aulacomnium turgidum & - & 0.0026 & 0.0033 & 0.027 & 0.00077 & 0.0057 \\
\hline Brachkthecium turgidum & - & 0.0018 & 0.0044 & 0.029 & 0.00195 & 0.0035 \\
\hline Calliergon stramineum & - & 0.0073 & 0.0061 & 0.029 & 0.00082 & 0.0040 \\
\hline Dicranum grocnlandicum & - & 0.0017 & 0.0037 & 0.016 & 0.00046 & 0.0029 \\
\hline Dicranum spadiceum & - & 0.0024 & 0.0030 & 0.017 & 0.00059 & 0.0057 \\
\hline Ditrichum flexicaule & - & 0.0008 & 0.0022 & 0.010 & 0.00044 & 0.0016 \\
\hline Hylocomium splendens & - & 0.0036 & 0.0061 & 0.024 & 0.00066 & 0.0065 \\
\hline Pleurozium schreberi & - & 0.0039 & 0.0029 & 0.019 & 0.00063 & 0.0060 \\
\hline
\end{tabular}




\begin{tabular}{|c|c|c|c|c|c|c|}
\hline Mosses & $\mathbf{M n}$ & $\mathbf{N i}$ & $\mathbf{C u}$ & $\mathbf{Z n}$ & $\mathbf{C d}$ & $\mathbf{P b}$ \\
\hline Polytrichum alpinum & - & 0.0023 & 0.0043 & 0.019 & 0.00042 & 0.0036 \\
\hline Polytrichum commune & - & 0.0017 & 0.0048 & 0.024 & 0.00026 & 0.0009 \\
\hline Racomitrium ericoides & - & 0.0126 & 0.0177 & 0.043 & 0.00082 & 0.0070 \\
\hline Racomitrium lanuginosum & - & 0.0024 & 0.0023 & 0.013 & 0.00031 & 0.0049 \\
\hline Sanionia uncinata & - & 0.0043 & 0.0060 & 0.021 & 0.00059 & 0.0071 \\
\hline Tomentypnum nitens & - & 0.0088 & 0.0059 & 0.027 & 0.00071 & 0.0064 \\
\hline Tortula ruralis & - & 0.0036 & 0.0069 & 0.032 & 0.00085 & 0.0052 \\
\hline Mean & - & 0.0043 & 0.0059 & 0.024 & 0.00069 & 0.0049 \\
\hline $\pm S D$ & - & 0.0033 & 0.0042 & 0.008 & 0.00038 & 0.0019 \\
\hline
\end{tabular}

Concentrations of heavy metals in mosses collected in Svalbard during the years 1987-1995 are presented in Table 10 [38].

Table 10

Mean concentrations of heavy metals $\mathrm{Ni}, \mathrm{Cu}, \mathrm{Zn}, \mathrm{Cd}$ and $\mathrm{Pb}$ accumulated in mosses collected during the years $1987-1995[\mathrm{mg} / \mathrm{g}][38]$

\begin{tabular}{|c|c|c|c|c|c|c|}
\hline Mosses & $\mathbf{M n}$ & $\mathbf{N i}$ & $\mathbf{C u}$ & $\mathbf{Z n}$ & $\mathbf{C d}$ & $\mathbf{P b}$ \\
\hline Aulacomnium spp. & 0.190 & - & 0.0123 & 0.058 & 0.0006 & 0.015 \\
\hline Bryum spp. & 0.206 & - & 0.0107 & 0.073 & 0.0008 & 0.015 \\
\hline Camphylium polygamum & 0.132 & - & 0.0168 & 0.086 & 0.0004 & 0.019 \\
\hline Catoscopium nigritum & 0.052 & - & 0.0120 & 0.064 & 0.0005 & 0.030 \\
\hline Dicranoweissia crispula & 0.143 & - & 0.0096 & 0.051 & 0.0004 & 0.028 \\
\hline Dicranum spp. & 0.037 & - & 0.0071 & 0.052 & 0.0007 & 0.014 \\
\hline Distichium capillaceum & 0.092 & - & 0.0041 & 0.025 & 0.0006 & 0.023 \\
\hline Drepanocladus spp. & 0.171 & - & 0.0099 & 0.038 & 0.0007 & 0.014 \\
\hline Hylocomium splendens & 0.048 & - & 0.0085 & 0.045 & 0.0007 & 0.025 \\
\hline Onocophorus wahlenbergii & 0.145 & - & 0.0059 & 0.054 & 0.0011 & 0.022 \\
\hline Pohlia spp. & 0.127 & - & 0.0108 & 0.069 & 0.0005 & 0.013 \\
\hline Ptilidium ciliare & 0.145 & - & 0.0032 & 0.054 & 0.0011 & 0.022 \\
\hline Racomitrium lanuginosum & 0.079 & - & 0.0039 & 0.038 & 0.0006 & 0.015 \\
\hline Schistidium apocarpum & 0.435 & - & 0.0067 & 0.049 & 0.0012 & 0.046 \\
\hline Sphagnum squamosum & 0.038 & - & 0.0061 & 0.047 & 0.0008 & 0.012 \\
\hline Tetralophozia setiformis & 0.047 & - & 0.0036 & 0.045 & 0.0005 & 0.012 \\
\hline Mean & 0.130 & - & 0.0082 & 0.053 & 0.0007 & 0.020 \\
\hline SSD & 0.099 & - & 0.0038 & 0.015 & 0.0003 & 0.009 \\
\hline
\end{tabular}

Studies of heavy metals plants growing in the western and northern part of Svalbard were carried out during the period from June to August 1988. The research used, among others, the mosses Tomenthypnum nitens and Racomitrium lanuginosum [39]. The results are presented in Table 11.

Mean concentrations of heavy metals accumulated in the mosses collected Svalbard in 1988 [mg/g]

\begin{tabular}{|c|c|c|c|c|c|c|}
\hline Moss & Mn & Ni & Cu & Zn & Cd & Pb \\
\hline Tomenthypnum nitens & 0.090 & 0.0064 & - & 0.032 & - & - \\
\hline Racomitrium lanuginosum & 0.024 & 0.0024 & 0.0031 & 0.012 & 0.0002 & 0.0073 \\
\hline
\end{tabular}

- below detection limit

Samples of lichens and mosses were collected in the southern parts of Svalbard in July and August 2008, in order to determine heavy metals accumulation. The research results 
(mean values) of the metals determined in the moss Racomitrium lanuginosum are presented in Table 12 [40].

Table 12

Mean concentrations of heavy metals accumulated in the moss Racomitrium lanuginosum collected in Svalbard in 2008 [mg/g]

\begin{tabular}{|c|c|c|c|c|c|}
\hline $\mathbf{M n}$ & $\mathbf{N i}$ & $\mathbf{C u}$ & $\mathbf{Z n}$ & $\mathbf{C d}$ & $\mathbf{P b}$ \\
\hline 0.010 & 0.0092 & 0.0038 & 0.011 & 0.00003 & 0.0029 \\
\hline
\end{tabular}

Heavy metals in Sanionia uncinata, from 29 sites in the southern part of Svalbard, was studied in 2008 [41]. Mean concentration values read from the graph are presented in Table 13.

Mean concentrations of heavy metals accumulated in the moss Sanionia uncinata collected for the research in Svalbard in 2008 [mg/g]

\begin{tabular}{|c|c|c|c|c|c|}
\hline $\mathbf{M n}$ & $\mathbf{N i}$ & $\mathbf{C u}$ & $\mathbf{Z n}$ & $\mathbf{C d}$ & $\mathbf{P b}$ \\
\hline- & 0.0030 & 0.0068 & 0.022 & 0.0003 & 0.005 \\
\hline
\end{tabular}

Similar research was carried out in 2011 in the south-western part of Svalbard, near the Polish Arctic Station in the Hornsund fjord. Table 14 presents the means values from 34 measurement sites [42].

Table 14

Mean concentrations of heavy metals accumulated in the mosses collected for the research in Svalbard in 2011 [mg/g]

\begin{tabular}{|c|c|c|c|c|c|c|}
\hline Mosses & $\mathbf{M n}$ & $\mathbf{N i}$ & $\mathbf{C u}$ & $\mathbf{Z n}$ & $\mathbf{C d}$ & $\mathbf{P b}$ \\
\hline Aulacomnium palustre & 0.019 & 0.0001 & 0.0034 & 0.020 & 0.0003 & 0.0006 \\
\hline Bryum pseudotriquetrum & 0.092 & 0.0016 & 0.0120 & 0.039 & 0.0003 & 0.0024 \\
\hline Plagiomnium ellipticum & 0.074 & 0.0005 & 0.0047 & 0.024 & 0.0005 & 0.0004 \\
\hline Racomitrium lanuginosum & 0.070 & 0.0040 & 0.0036 & 0.011 & 0.00004 & 0.0030 \\
\hline Sanionia uncinata & 0.130 & 0.0050 & 0.0090 & 0.026 & 0.0001 & 0.0032 \\
\hline Straminergon stramineum & 0.033 & 0.0003 & 0.0044 & 0.022 & 0.0002 & 0.0011 \\
\hline Tetraplodon mnioides & 0.018 & 0.0008 & 0.0032 & 0.024 & 0.0004 & 0.0006 \\
\hline Warnstorfia sarmentosa & 0.430 & 0.0130 & 0.0170 & 0.036 & 0.0002 & 0.0080 \\
\hline Mean & 0.108 & 0.0032 & 0.0072 & 0.025 & 0.0003 & 0.0024 \\
\hline \pm SD & 0.135 & 0.0044 & 0.0051 & 0.009 & 0.0002 & 0.0025 \\
\hline
\end{tabular}

The results presented in Tables 3-14 were interpreted taking into consideration the long-term changes of pollution levels of the studied ecosystems. Comparisons were also carried out, in order to establish an order of pollution levels of the studied areas.

For the comparison purposes, the graph in Figure 3 presents mean values of concentrations of heavy metals: $\mathrm{Mn}, \mathrm{Ni}, \mathrm{Cu}, \mathrm{Zn}, \mathrm{Cd}$ and $\mathrm{Pb}$ accumulated in different species of mosses collected for the research in Svalbard during the years 1985-2011. It should be emphazised that the species of mosses collected in Svalbard (Tables 9-14) differ in adsorption characteristics, which is confirmed by large standard deviations of the results, versus the mean values (Tables 9, 10 and 14). Therefore, due to the lack of the possibility to verify the data, in order to determine the reference values, the mean values of all presented results were accepted. 


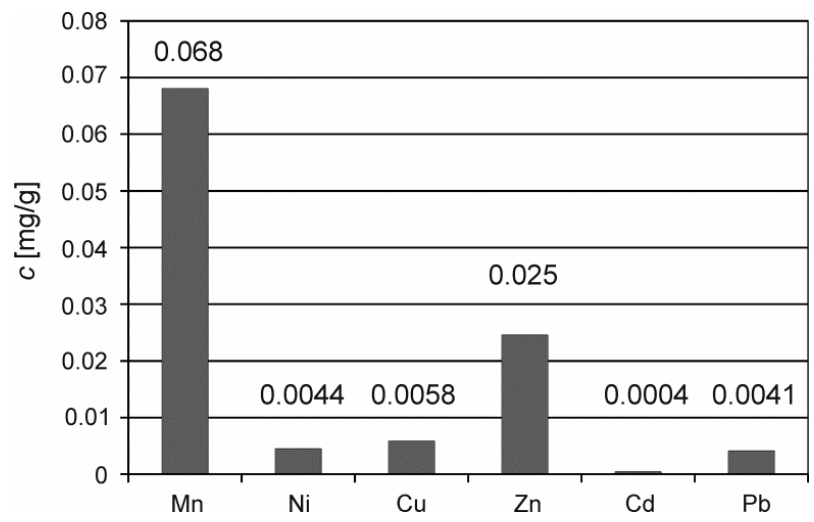

Fig. 3. Mean values of concentrations of heavy metals accumulated in various species of mosses collected in Svalbard during the years 1985-2011

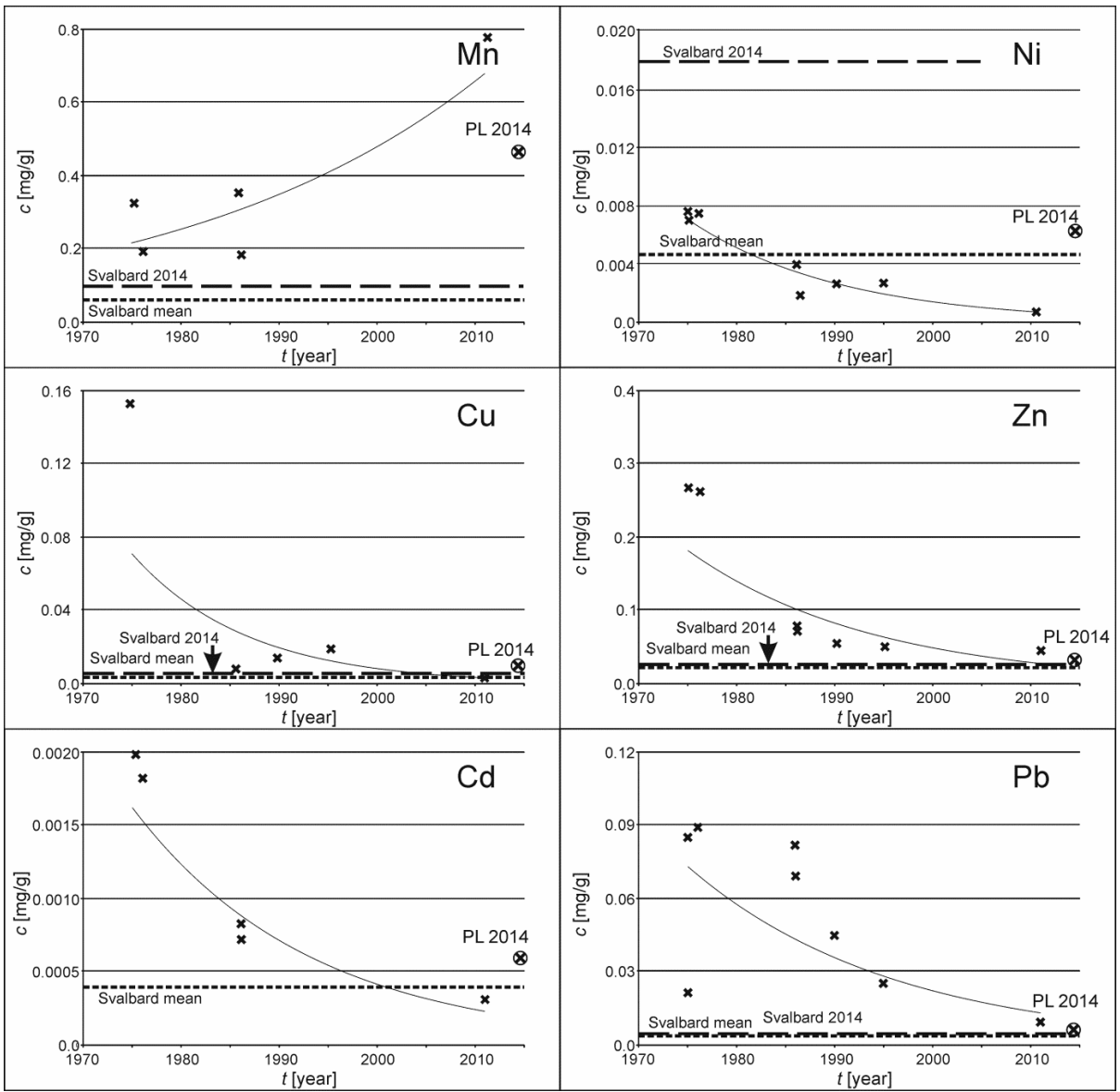

Fig. 4. Changes of concentrations of $\mathrm{Mn}, \mathrm{Ni}, \mathrm{Cu}, \mathrm{Zn}, \mathrm{Cd}$ and $\mathrm{Pb}$ accumulated in the mosses collected in Karkonosze 
The graphs in Figures 4-6 present changes of concentrations of heavy metals accumulated in the mosses collected for the research in Karkonosze, Beskidy and woodlands of the north-eastern Poland, during the years 1975-2011. The results were compared to the presented in Figure 3 mean values of concentrations determined in the mosses collected in Svalbard (Svalbard mean), to the summarised in Table 3 mean values of concentrations of the metals determined in the mosses collected in Poland in 2014 (PL 2014) and to the summarised in Table 4 mean values of concentrations of the metals determined in the moss collected in Svalbard in 2014 (Svalbard 2014). The projected changes of concentrations were approximated by the exponential function.

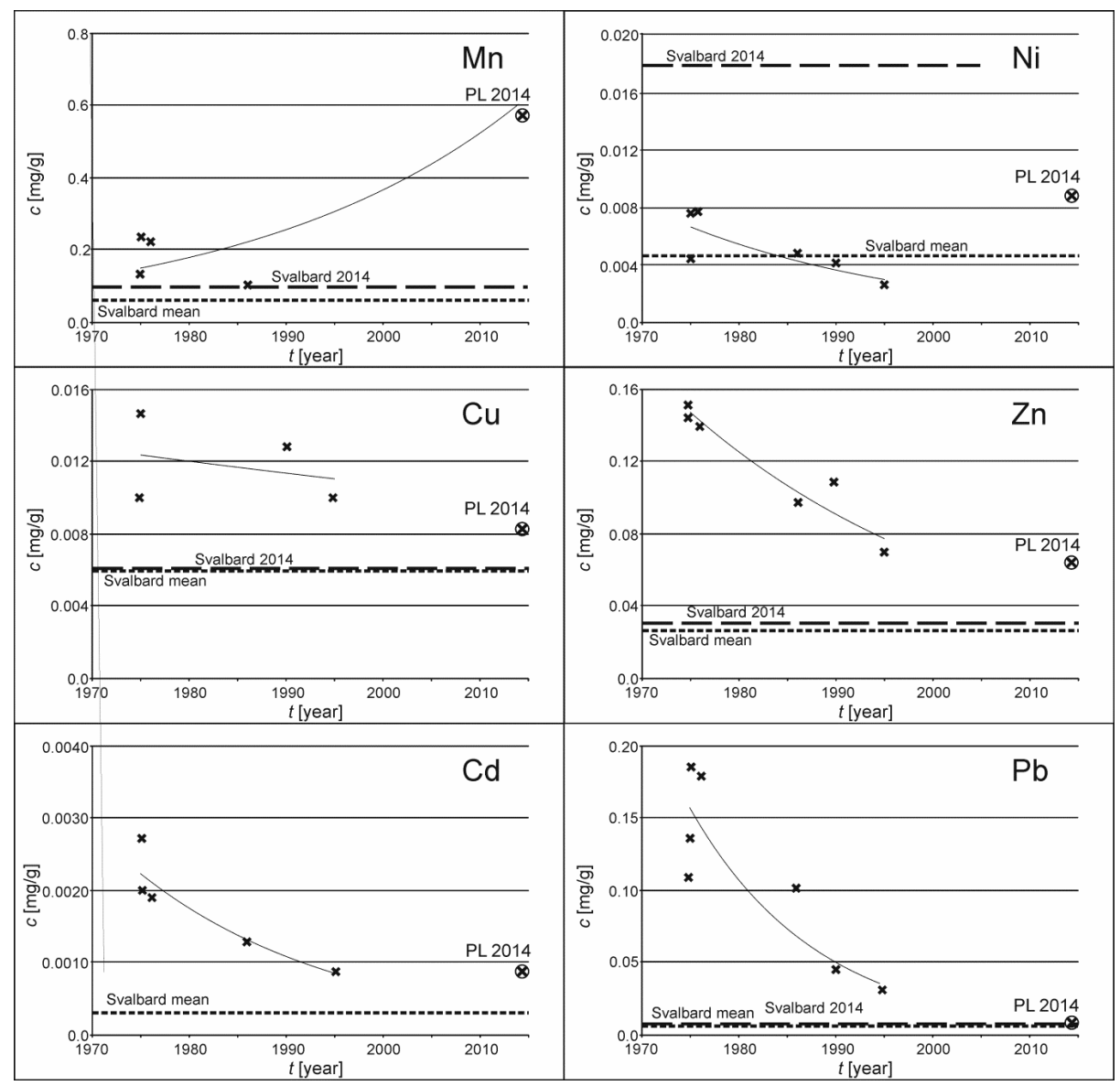

Fig. 5. Changes of concentrations of $\mathrm{Mn}, \mathrm{Ni}, \mathrm{Cu}, \mathrm{Zn}, \mathrm{Cd}$ and $\mathrm{Pb}$ accumulated in the mosses collected in Beskidy

The results presented in the graphs show a positive trend of historical changes of concentrations of $\mathrm{Cu}, \mathrm{Zn}, \mathrm{Cd}$ and $\mathrm{Pb}$ accumulated in the mosses collected in Poland. In comparison to 1975, the mean concentration of copper accumulated in the mosses 
collected in 2014 in Karkonosze, Beskidy and woodlands of the north-eastern Poland decreased by 93,43 and $55 \%$, respectively.

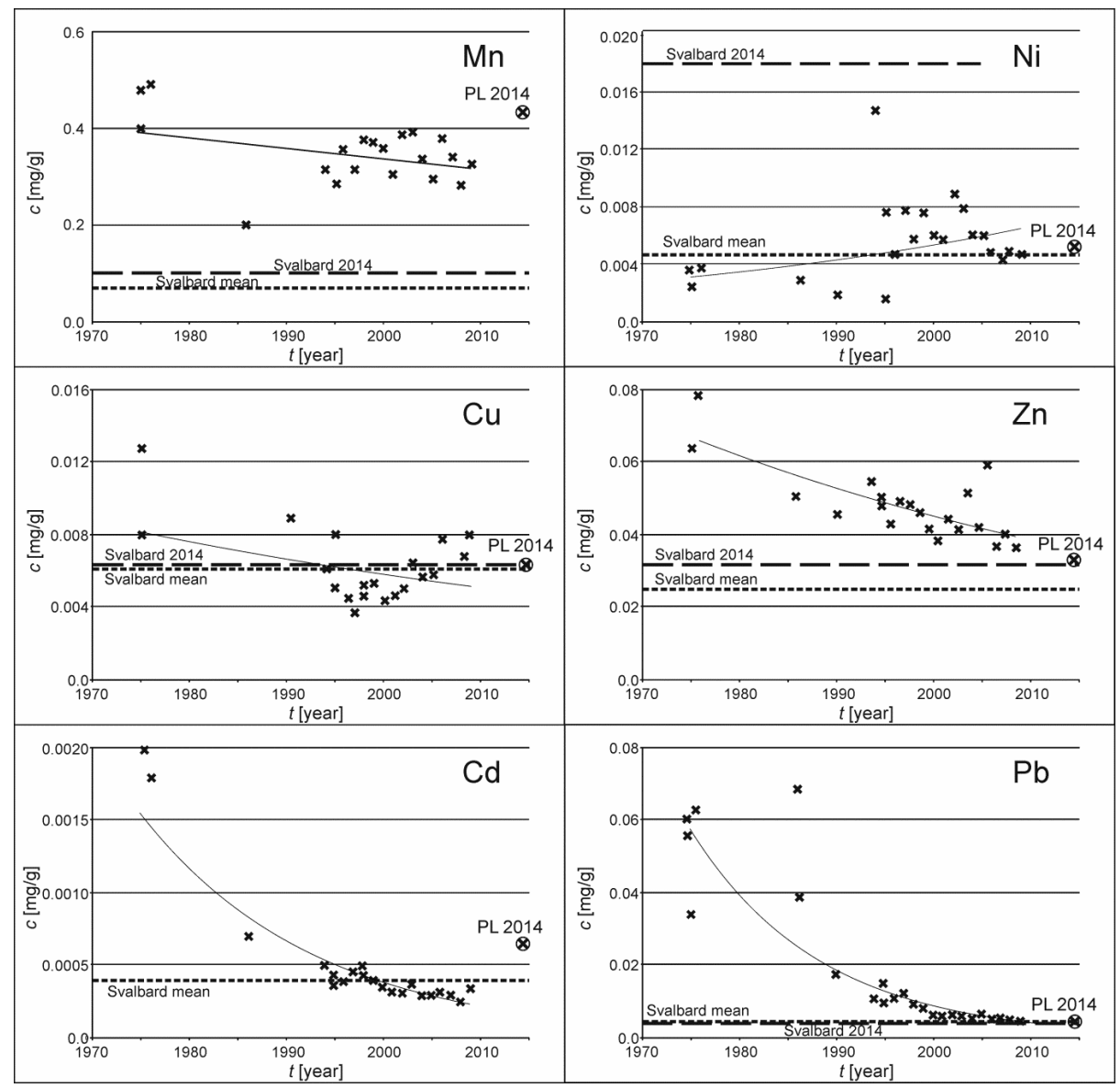

Fig. 6. Changes of concentrations of $\mathrm{Mn}, \mathrm{Ni}, \mathrm{Cu}, \mathrm{Zn}, \mathrm{Cd}$ and $\mathrm{Pb}$ accumulated in the mosses collected in the woodlands of the north-eastern Poland

The mean concentrations of zinc in the samples of mosses collected in 2014, compared to 1975 , decreased by $87 \%$ in Karkonosze, $59 \%$ in Beskidy and $54 \%$ in the woodlands of the north-eastern Poland. The mean concentration of cadmium decreased by over 70, 68 and $67 \%$ respectively, and lead by over 38,52 and $23 \%$. The changes trend also shows decrease of nickel concentrations in the mosses growing in Karkonosze and Beskidy, however, this has not been confirmed by the results of the research from 2014. Concentrations of nickel in the mosses collected in 2014 in the north-eastern Poland decrease versus the abnormal, relatively high concentrations recorded in 1994. The considerable decrease of concentration of $\mathrm{Cu}, \mathrm{Zn}, \mathrm{Cd}$ and $\mathrm{Pb}$ in the samples of mosses from Karkonosze is the result of the implemented rehabilitation program, which aimed at reduction of emission from the browncoal-fuelled power plants located near $(50-100 \mathrm{~km})$ the study area, in Poland, Czech and 
Germany, at the junction of borders of these countries. Currently in Poland significant contribution in environmental pollution is delivered with uncontrolled low emission from households [43]. No major changes of manganese concentration were recorded in the moss samples collected in the studied areas in 2014. This may be caused by the secondary pollution of atmospheric aerosol with the manganese originating from the soil.

Taking into consideration the mean concentrations of metals in the moss samples collected in 2014 and the trends of the changes in long-term perspective, it is possible to order the studied areas by the pollution level: Beskidy > Karkonosze > woodlands of the north-eastern Poland. As mentioned above, the area of Beskidy is under the influence of emission from Upper Silesia Industrial Zone (PL) and Ostrava-Karvina Coal Basin (CZ). Concentrations of the studied metals (apart from manganese) in the samples collected in 2014 in the woodlands of the north-eastern Poland are comparable to concentrations of metals determined in the mosses collected in Svalbard. Concentrations of $\mathrm{Cu}, \mathrm{Zn}$ and $\mathrm{Pb}$ in the samples collected in 2014 in Karkonosze are also comparable to mean values of concentrations in the moss samples from Svalbard.

Considerably large concentrations of nickel (mean $0.0180 \mathrm{mg} / \mathrm{g}$ ), also in comparison to the mean long-term value for this area (mean $0.0044 \mathrm{mg} / \mathrm{g}$ ) were recorded in the samples of mosses collected in Svalbard in 2014. The origins of nickel content biota and soil in Svalbard can originate from long transported industrial air pollution from the Kola Peninsula [23, 44, 45]. However, it should be emphasized that the mean nickel concentration in Svalbard was determined on the basis of nickel concentrations in the samples of moss collected mainly in the south of Spitsbergen, whereas in 2014, the samples of moss were collected in 7 sites near and within Longyearbyen a coal mining town and area, near a coal fueled electrical power plant. According to Elberling et al 2007 and Aaskaer et al 2008 the main source of pollutants are the mining waste in the rock piles in the area and they have measured similar contents of nickel, manganese and zinc in biota and soil in some of the rock pile areas as we have measured in our sites. In addition air pollutants may originate from the port area where the shipping of coal from the local mine is located, faeces from the sea bird colonies and pollution from the airport (Fig. 2). Nickel superalloys are used in construction of aircraft engines [46].

\section{Conclusions}

The analyses of the results of the presented biomonitoring research carried out during the years 1975-2014 indicate improvement of environment quality in the studied areas of Poland. Mean concentrations of $\mathrm{Ni}, \mathrm{Cu}, \mathrm{Zn}, \mathrm{Cd}$ and $\mathrm{Pb}$ in the samples collected in 2014 in the woodlands of north-eastern Poland are comparable to mean concentrations of metals determined in mosses collected in the Svalbard archipelago during the last three decades. Concentrations of $\mathrm{Cu}, \mathrm{Zn}$ and $\mathrm{Pb}$ in the samples collected in 2014 in Karkonosze are also comparable to mean concentration values in moss samples from Svalbard. Relatively higher values were recorded in mosses collected in Beskidy. Apart from a general assessment of environment pollution and the undergoing changes in the environment, bio-monitoring with the use of mosses is considered a good method to discover anomalies, an example of which is the detection of relatively high concentration of nickel accumulated in mosses collected near Longyearbyen (Spitsbergen) in 2014. 


\section{Acknowledgements}

The study was performed within the framework of the project: Ecosystem stress from the combined effects of winter climate change and air pollution - how do the impacts differ between biomes? (WICLAP) Polish Norwegian Research Programme (NCRD) POL-NOR / $198571 / 83 / 2013$.

\section{References}

[1] Głuszcz P, Zakrzewska K, Wagner-Doebler I, Ledakowicz S. Bioreduction of ionic mercury from wastewater in a fixed-bed bioreactor with activated carbon. Chem Pap. 2008;62(3):232-238. DOI: 10.2478/s11696-008-0017-z.

[2] Travnikov O. Contribution of the intercontinental atmospheric transport to mercury pollution in the Northern Hemisphere. Atmos Environ. 2005;39:7541-7548.

[3] Wolterbeek B. Biomonitoring of trace element air pollution: principles possibilities and perspectives. Proc. of the International Workshop - BioMAP II. 28 August - 3 September 2000. Vienna, Austria; 2003:87-104.

[4] Markert B, Breure A, Zechmeister H. Bioindicators \& Biomonitors: Principles. Concepts and Applications. Amsterdam: Elsevier; 2003.

[5] Smodiš B, Pignata ML, Saiki M, Cortés E, Bangfa N, Markert B, et al. Validation and application of plants as biomonitors of trace element atmospheric pollution - A co-ordinated effort in 14 countries. J Atmos Chem. 2004;49:3-13.

[6] Markert B. Definitions and principles for bioindication and biomonitoring of trace metals in the environment. J Trace Elem Med Biol. 2007;21(S1):77-82. DOI: 10.1016/j.jtemb.2007.09.015.

[7] Wardencki W, editor. Bioanalityka w ocenie zanieczyszczeń środowiska. Gdańsk: CEEAM; 2004.

[8] Olszowski T, Tomaszewska B, Goralna-Wlodarczyk K. Air quality in non-industrialised area in the typical Polish countryside based on measurements of selected pollutants in immission and deposition phase. Atmos Environ. 2012;50:139-147. DOI: 10.1016/j.atmosenv.2011.12.049.

[9] Kłos A, Rajfur M, Wacławek M, Wacławek W. ${ }^{137}$ Cs transfer from local particulate matter to lichens and mosses. Nukleonika. 2009;54(4):297-303.

[10] Dołhanczuk-Śródka A, Majcherczyk T, Smuda M, Ziembik Z, Wacławek M. Spatial Cs-137 distribution in forest soil. Nukleonika. 2006;51(2):569-579.

[11] Rühling A, Tyler G. An ecological approach to the lead problem. Botan Notis. 1968;121:321-342.

[12] Freitas MC, Reis MA, Alves LC, Wolterbeek HTh. Distribution in Portugal of some pollutants in the lichen Parmelia sulcata. Environ Pollut. 1999;106:229-235.

[13] Freitas MC, Reis MA, Marques AP, Almeida SM, Farinha MM, de Oliveira O, et al. Monitoring of environmental contaminants: 10 years of application of k0-INAA. J Radioanal Nucl Chem. 2003;257(3):621-625

[14] Kłos A, Rajfur M, Šrámek I, Wacławek M. Use of lichen and moss in assessment of forest contamination with heavy metals in Praded and Glacensis Euroregions (Poland and Czech Republic). Water Air Soil Pollut. 2011;222:367-376. DOI: 10.1007/s11270-011-0830-9.

[15] Kłos A, Rajfur M, Šrámek I, Wacławek M. Mercury concentration in lichen, moss and soil samples collected from the forest areas of Praded and Glacensis Euroregions (Poland and Czech Republic). Environ Monit Assess. 2012;184:6765-6774. DOI: 10.1007/s10661-011-2456-1.

[16] Kłos A, Rajfur M, Wacławek M, Wacławek W, Frontasyeva MV, Pankratova JS. The influence of unidentified pollution sources on the irregularity of biomonitoring tests results. Water Air Soil Pollut. 2008;191:345-352. DOI: 10.1007/s11270-008-9629-8.

[17] Matuszkiewicz JM. Potencjalna roślinność naturalna Polski (Potential natural vegetation of Poland). Warszawa: IGiPZ PAN; 2008.

[18] Troc M, Jelonek A, editors. Svalbard - Encyklopedia Geograficzna Świata - tom V Europa. Kraków: OPRESS; 1996.

[19] Nowosielski L. Klimat Spitsbergenu. Gazeta Obserwatora IMGW. 2004;2:14-17.

[20] Maciejowski W. Walory turystyczne i formy turystyki w archipelagu Svalbard (Norwegia). Studia nad turystyką. Prac geograf regional. 2007: Kraków: IGiGP UJ; 123-134.

[21] Araźny A. Bioklimat Arktyki Norweskiej i jego zmienność w okresie 1971-2000. Toruń: Wyd Nauk Uniwersytetu Mikołaja Kopernika: 2008. 
[22] Johansen BF, Prestvold K, Overrein Ø. The Cruise Handbook for Svalbard. Tromsø: Norwegian Polar Institute; 2011.

[23] AMAP Assessment 2006: Acidifying Pollutants, Arctic Haze, and Acidification in the Arctic, Oslo: Arctic Monitoring and Assessment Programme; 2006.

[24] Gabrielsen GW, Evenset A, Frantzen S, Gwynn J, Hallanger IG, Kallenborn R, et al. MOSJ statusrapport 2011 Miljøgifter. Norsk Polarinstitutt Rapportserie 137. Norwegian Polar Institute; 2011.

[25] Elberling B, Søndergaard J, Jensen LA, Schmidt LB, Hansen BU, Asmund, G, et al. Arctic vegetation damage by winter-generated coal mining pollution released upon thawing. Environ Sci Technol. 2007;41:2407-2413.

[26] Askaer L, Schmidt LB, Elberling B, Asmund G, Jónsdóttir IS. Environmental impact on an Arctic soil-plant system resulting from metals released from coal mine waste in Svalbard $\left(78^{\circ} \mathrm{N}\right)$. Water Air Soil Pollut. 2008;195:99-114.

[27] Headley AD. Heavy metals in peat from the high Arctic. Sci Total Environ. 1995;177: 105-111.

[28] Grodzińska K. Mosses as bioindicators of heavy metal pollution in polish national parks. Water Air Soil Pollut. 1978;9:83-97.

[29] Grodzińska K, Szarek G, Godzik B. Heavy metal deposition in polish national parks - changes during ten years. Water Air Soil Pollut. 1990;49:409-419.

[30] Herpin U, Berlekamp J, Markert B, Wolterbeek B, Grodzińska K, Siewers U, et al. The distribution of heavy metals in a transect of the three states the Netherlands, Germany and Poland determined with the aid of moss monitoring. Sci Total Environ. 1996;187:185-198.

[31] Grodzińska K, Szarek-Łukaszewska G, Godzik B. Survey of heavy metal deposition in Poland using mosses as indicators. Sci Total Environ. 1999;229:41-51

[32] Grodzińska K, Szarek-Łukaszewska G. Response of mosses to the heavy metal deposition in Poland an overview. Environ Pollut. 2001;114:443-451.

[33] Malzahn E. Biomonitoring środowiska leśnego Puszczy Białowieskiej. Ochr Środow Zasob Natural. 2009;40:439-447.

[34] Malzahn E, Wójcik J. Metody stosowane w bioindykacji środowiska leśnego Puszczy Białowieskiej. Acta Agrophys. 2012;19(2):355-364.

[35] Grodzińska K, Frontasyeva M, Szarek-Łukaszewska G, Klich M, Kucharska-Fabiś A, Gundorina SF, et al. Trace element contamination in industrial regions of Poland studied by moss monitoring. Environ Monit Assess. 2003;87:255-270.

[36] Wojtuń B, Samecka-Cymerman A, Kolon K, Kempers AJ. Decreasing concentrations of metals in Sphagnum mosses in ombrotrophic mires of the Sudety mountains (SW Poland) since late 1980s. Chemosphere. 2013;91:1456-1461.

[37] Grodzińska K, Godzik B. Heavy metals and sulphur in mosses from southern Spitsbergen. Polar Res. 1991;9(2):133-140.

[38] Jóźwik Z. Heavy metals in tundra plants of the Bellsund in West Spitsbergen, investigated in the years 1987-1995. Pol Polar Res. 2000;21(1):43-54.

[39] Drbal K, Elster J, Komárek J. Heavy metals in water, ice and biological material from Spitsbergen, Svalbard. Polar Res. 1992;11(2):99-101.

[40] Węgrzyn M, Lisowska M, Nicia P. The value of the terricolous lichen Cetrariella delisei in the biomonitoring of heavy-metal levels in Svalbard. Pol Polar Res. 2013;34(4):375-382. DOI: 10.2478/popore-2013-0022.

[41] Samecka-Cymerman A, Wojtuń B, Kolon K, Kempers AJ. Sanionia uncinata (Hedw.) loeske as bioindicator of metal in polar regions. Polar Biol. 2011;34:381-388. DOI: 10.1007/s00300-010-0893-x.

[42] Wojtuń B, Samecka-Cymerman A, Kolon K, Kempers AJ, Skrzypek G. Metals in some dominant vascular plants. Mosses; Lichens, algae and the biological soil crust in various types of terrestrial tundra. SW Spitsbergen. Norway. Polar Biol. 2013; 36:1799-1809. DOI 10.1007/s00300-013-1399-0.

[43] Olszowski T, Bożym M. Pilot study on using an alternative method of estimating emission of heavy metals from wood combustion. Atmos Environ. 2014;94:22-27, DOI: 10.1016/j.atmosenv.2014.05.011.

[44] Tømmervik H, Høgda KA, Solheim I. Monitoring vegetation changes in Pasvik (Norway) and Pechenga in Kola Peninsula (Russia) using multitemporal Landsat MSS/TM data. Remote Sensing of Environ. 2003;85:370-388.

[45] Bjerke JW, Tømmervik H, Finne TE, Jensen H, Lukina N, Bakkestuen V. Epiphytic lichen distribution and plant leaf heavy metal concentrations in Russian-Norwegian boreal forests influenced by air pollution from nickel-copper smelters. Boreal Environ Res. 2006;11:441-450. 
[46] Pollock TM, Tin S. Nickel-based super-alloys for advanced turbine engines: chemistry, microstructure, and properties. J Propul Power. 2006;22(2):361-374.

\title{
WYKORZYSTANIE MCHÓW W BIOMONITORINGU WYBRANYCH OBSZARÓW W POLSCE I NA SPITSBERGENIE W LATACH 1975-2014
}

\author{
${ }^{1}$ Samodzielna Katedra Biotechnologii i Biologii Molekularnej, Uniwersytet Opolski, Opole, Polska \\ ${ }^{2}$ Instytut Geodezji i Kartografii, Warszawa, Polska \\ ${ }^{3}$ Norwegian Institute for Nature Research - NINA, FRAM - High North Research Centre for Climate \\ and the Environment, Troms $\varnothing$, Norwegia \\ ${ }^{4}$ Wydział Geografii i Studiów Regionalnych, Uniwersytet Warszawski, Warszawa, Polska
}

\begin{abstract}
Abstrakt: Przeanalizowano historyczne zmiany stężeń metali ciężkich: $\mathrm{Mn}, \mathrm{Ni}, \mathrm{Cu}, \mathrm{Zn}, \mathrm{Cd}$ i Pb zakumulowanych w próbkach mchów pobieranych do badań w Polsce, na terenach leśnych Beskidów i Karkonoszy oraz w lasach północno-wschodniej części kraju, w odniesieniu do mało zanieczyszczonych obszarów Archipelagu Svalbard, którego największą wyspą jest Spitsbergen. Wyniki badań przedstawianych w literaturze uzupełniono wynikami badań własnych, prowadzonych w 2014 r. Wykazano, że spośród wymienionych obszary Beskidów oraz Karkonoszy były i są najbardziej narażone na depozycję metali ciężkich. Stwierdzono również, że na przestrzeni lat 1975-2014 nastąpiło znaczące zmniejszenie stężeń $\mathrm{Cu}, \mathrm{Zn}, \mathrm{Cd}$ i $\mathrm{Pb}$ w mchach porastających wszystkie analizowane obszary na terenie Polski, co świadczy o poprawie jakości środowiska. Dla przykładu, w próbkach mchów pobieranych na obszarze Karkonoszy w 1975 r. średnie stężenie Cd wynosiło 0,002 $\mathrm{mg} / \mathrm{g}$, natomiast w 2014 r. średnie stężenie Cd zakumulowanego w mchach było mniejsze od 0,0006 mg/g. Interesujące są stosunkowo duże stężenia niklu w próbkach mchów pobranych w 2014 r. na obszarze Archipelagu Svalbard w pobliżu Longyearbyen (średnia $0,018 \mathrm{mg} / \mathrm{g}$ ).
\end{abstract}

Słowa kluczowe: biomonitoring, metale ciężkie, mchy, Polska, Svalbard 